\title{
Topical Toxicity of Esenbeckia pumila Extracts on Leaf-Cutting Ants Atta laevigata and Acromyrmex balzani
}

\author{
Brenda R. Souza ${ }^{1}$, Gustavo M. Coelho ${ }^{1}$, Ednaldo C. Rocha ${ }^{1}$, Flávio G. Jesus ${ }^{2}$, Antônio C. S. Menezes ${ }^{3}$ \\ \& Márcio S. Araújo ${ }^{1}$ \\ ${ }^{1}$ Universidade Estadual de Goiás, Câmpus Ipameri, Ipameri, GO, Brazil \\ ${ }^{2}$ Instituto Federal Goiano, Campus Urutaí, Urutaí, GO, Brazil \\ ${ }^{3}$ Universidade Estadual de Goiás, Câmpus Anápolis, Anápolis, GO, Brazil \\ Correspondence: Márcio S. Araújo, Universidade Estadual de Goiás, Câmpus Ipameri, Ipameri, GO, Brazil. Tel: \\ 55-64-3491-3801.E-mail: marcio.araujo@ueg.br
}

Received: August 27, 2017

Accepted: October 10, $2017 \quad$ Online Published: November 15, 2017

doi:10.5539/jas.v9n12p248

URL: https://doi.org/10.5539/jas.v9n12p248

\begin{abstract}
The aim of this study was to evaluate the topical toxicity of the Esenbeckia pumila plant extracts on workers of the Atta laevigata and Acromyrmex balzani. Five leaf fractions E. pumila were drawn viz., the hexane, ethanolic, dichloromethane, ethyl acetate and methanolic extracts, as well as the ethanolic fruit extracts. Further, the phytochemical leaf extract exploration was performed, and the secondary compounds detected were as follows: flavonoids, anthraquinones, coumarins, cardioactive heterosides and tannins. The different leaf and fruit extract fractions were first diluted in $70 \%$ ethyl alcohol, and different doses were topically applied to the A. laevigata and $A$. balzani workers. All the fractions extracted exhibited formicidal effects and this effect was greater to $A$. laevigata rather than to A. balzani. Only a small percentage of the workers succumbed within the first few hours of application of the different extracts in comparison with the workers which died only after a longer exposure time (72 h) implying a delayed effect of $E$. pumila extracts.
\end{abstract}

Keywords: botanical insecticide, toxicity tests, phytochemical prospecting, Attini

\section{Introduction}

In the catalog, Grainge and Ahmed (1988) recorded that about 2,400 plant species could have insecticidal properties. According to Aguiar-Menezes (2005), the plant families possessing such properties include Meliaceae, Rutaceae, Asteraceae, Annonaceae, Labiatae and Canellaceae. Although the toxic effects of a few insecticides of vegetable origin are well recognized like nicotine, azadirachtin, the rotenones and pyrethrins, very little information is available regarding other potential toxic plants that inhibit the action mechanism of the insects, particularly for leaf-cutting ants and their symbiont fungus.

Plant ingredients may exhibit toxic or undersirable effects on no-target organisms, including humans. However, mostly plant insecticides are inherently less harmful than conventional pesticides (Upadhyay, 2012). They usually affect only the target and closely related organims, in contrast to broad spectrum, conventional insecticides that may also affect organisms as different from insects as bird and mammals (Solecki, 2004). Further, small industries and the farmers themselves can easily produce them (Mazzonetto \& Vendramim, 2003; Baskar \& Ignacimuthu, 2012). In the target insects, the plant insecticides induce inhibition of food, decreased motility, interference in the intestinal synthesis of ecdysonium, inhibition of the chitin biosynthesis, strain pupae and adults, minimized fecundity and longevity, sterilization, inhibition of oviposition and mortality of both the immature and adult stages (Baskar, Maheswaran, Kingsley, \& Ignacimuthu, 2011; Vendan, Baskar, Paulraj, \& Ignacimuthu, 2016).

Several studies have indicated the formicidal effect or other adverse effects on the ant colonies, particularly in the Atta spp.: Eucalyptus maculata by Marsaro Júnior et al. (2004), Sesamum indicum by Morini et al. (2005), Ricinus comunis by Hebling, Maroti, Bueno, Silva, and Pagnocca (1996), Datura stramonium, Cordia verbenacea, Mentha piperita and Ageratum conyzoides by Araújo et al. (2008) and Clavija weberbaueri, Mayna parviflora, Ryania speciosa, Spilanthes oleraceae and Siparuna amazonica by Gouvêa et al. (2010). The toxicity of some extract of Rutaceae such Helietta puberula, Ruta graveolens and Esenbeckia grandiflora has been 
investigated to Atta sexdens and A. laevigata (Almeida et al., 2007; Araújo et al., 2008; Gomes, Paula, Moreira, Castellani, \& Macedo, 2016). The majority of these studies are solely focused on the raw extracts or chemical compounds isolated from a few of them, specifically for the leaf-cutting ants; however, no practical application has been proposed, which is indicative of the huge possibilities opening up in the discovery of new products to use in pest control.

The Rutaceae family is highly recognized by a single genus, Citrus, highly popular for human consumption. This family is very well represented (includes 160 genera and 1900 species), it has a worldwide distribution across tropical, subtropical and temperate regions, but is most profuse in Tropical America, Southern Africa and Australia (Groppo, Pirani, Salatino, Blanco, \& Kallunki, 2008). In Brazil, this family includes 29 genera and 182 species (Barroso et al., 1986; Melo \& Zickel, 2004). The genus Esenbeckia, native to the Tropical Americas (Mabberley, 2008), studied in much detail in this work, includes the Esenbeckia pumila, which comprises about 20 species. According to Medeiros (2011), this shrub thrives in Brazil along the edges of "Mata de Galeria", "Cerrado" (strictly speaking) and "Campos Sujos", distributed across the states of Tocantins, Piauí, Bahia, Mato Grosso, Goiás, Minas Gerais and Federal District.

This plant family is a principal producer of secondary metabolites, such as terpenoids, limonoids, proto-limonoids, coumarins, alkaloids and lignins (Paula et al., 1997; Simpson \& Jacobs, 2005), and it has been intensely studied for its utility as a drug, herbicide and antimicrobial agent. It has also been drawing great attention as a natural source of insecticidal compounds (Almeida et al., 2007). However, no earlier report is available on the chemical composition of E. pumila; it also does not show the presence of secondary compounds with formicidal properties. The aim of this study was to evaluate the effect of the leaf and fruit extracts of Rutaceae E. pumila on the workers of A. laevigata and A. balzani, two leaf-cutting ants of economic significance in Latin American, mainly Brazil.

\section{Materials and Methods}

\subsection{Preparation and Phytochemical Prospection of Plant Extracts}

E. pumila plants were gathered in the "Cerrado" region, in Anápolis, GO, Brazil (lat. 16 $19^{\prime} 36^{\prime}$ S; Long. $48^{\circ} 57^{\prime} 10^{\prime \prime} \mathrm{W}$; alt. $1017 \mathrm{~m}$ ). From these plants, around $3.0 \mathrm{~kg}$ of the leaves of the upper third and $0.5 \mathrm{~kg}$ of none mature fruits were collected. The vegetable material was oven dried $\left(45^{\circ} \mathrm{C}\right)$ for 48 hours and ground in a knife mill. The ground material (leaves and fruits separately) was then immersed in $95 \%$ ethanol. This material was then macerated in the cold, and later filtered and concentrated in a rotary evaporator, producing ethanolic $E$. pumila leaf and fruit extracts (EPFE and EPFrE, respectively).

The ethanolic E. pumila leaf extracts (EPFE) were fractionated employing solvents in order of increasing polarity (hexane $<$ dichloromethane $<$ ethyl acetate $<$ methanol). Once the microcrystalline cellulose D was incorporated into the ethanolic extract and vacuum filtration was performed. Four leaf fractions were obtained, viz., hexane leaf extracts of E. pumila (EPFEH), dichloromethane leaf extract of E. pumila (EPFED), ethyl acetate leaf extract of E. pumila (EPFEA) and the methanolic leaf extract of E. pumila (EPFEM).

Both ethanolic extracts as well as all E. pumila leaf fractions were storage in the dark under refrigeration until further use in the biological tests. Phenolic compounds (simple phenols, flavonoids, anthraquinones, coumarins and tannins), nitrogen compounds (alkaloids) and terpenes (cardiac heterosides and saponins) were analyzed in $E$. pumila leaf fractions following the method adapted from J. M. D. Matos and M. E. Matos (1989), Matos (2009), Simões (2010), and Costa (2001).

The analytical procedure used for the identification of the secondary metabolites were as follows: FLAVONOIDS - colorimetric (Shinoda, Sodium Hydroxide and Ferric Chloride) and fluorescence under ultraviolet light (Oxalo-boric, Sulfuric Acid, Aluminum Chloride and Potassium Hydroxide); ANTHRAQUINONES - Bornträger Indirect; COUMARINS - Fluorescence under ultraviolet light potentiated with sodium hydroxide; CARDIOACTIVE HETEROSIDES - Liebermann-Burchard, Pesez, Keller-Kiliam and Kedde; TANNINS - precipitation (Gelatin, Quinine Sulfate, Brucine Sulfate, Copper Acetate and Ferric Chloride) and Colorimetric (Sodium Hydroxide); ALKALOIDS - Mayer, Dragendorff, Bouchardat, Bertrand \& Hager and Tannic Acid; SAPONINS - Shake foam.

\subsection{Biological Assays}

For the biological assays conducted in the Entomology Laboratory of the State University of Goiás, in Ipameri, Goiás, room temperature of $25 \pm 2{ }^{\circ} \mathrm{C}$, relative humidity of $70 \pm 10 \%$ and total scotophase were maintained. 


\subsection{The Workers of Leaf-Cutting Ants}

A. laevigata workers were drawn from 20 colonies selected from contiguous expanses of pasture, the "Cerrado" and commercial Eucalyptus sp. plantation situated in the Experimental Farm of the UEG, in Ipameri, GO, Brazil (lat. $17^{\circ} 43^{\prime} 29^{\prime \prime} \mathrm{S}$; Long. $48^{\circ} 9^{\prime} 35^{\prime \prime} \mathrm{W}$; alt. $764 \mathrm{~m}$ ). The A. balzani workers were also drawn from 20 colonies in the same area, but limited to only the pasture region showing the preponderance of Paspalum notatum grass, where they were easily identified. All the colonies selected were regarded as "good activity" foraging, implying the strong inflow of the foraging workers transporting the cut vegetation fragments into the interior portions of the colony, which demonstrated its integrity. Such as Araújo et al. (2008), the size of workers for the biological assay was standardized (the larger sized individuals within the respective colonies were used). The cephalic capsule length for A. balzani was $3.0 \pm 0.677 \mathrm{~mm}$ and that of A. laevigata was $4.6 \pm 0.516 \mathrm{~mm}$. These workers were randomly gathered from the active scouts at the colony entrances during the peak foraging times.

\subsection{Topical Application of Extracts}

The dosages of E. pumila leaf fractions (EPFEH, EPFED, EPFEA and EPFEM), as well as ethanolic fruit extracts of E. pumila (EPFrE) were applied topically in the notal regions of the ant workers, using $70 \%$ ethyl alcohol as solvent. Preliminary studies showed that ethyl alcohol provided the best dilution of the extracts, while only slight damaging effect was obserbed in the control treatment.

A single-dose of the extracts (i.e. $1.0 \mu \mathrm{L}$ ) were applied at the following concentrations $0.1,0.5,4.0,7.0,50.0$, 100.0 and $200.0 \mathrm{mg} \mathrm{mL}^{-1}$. To accomplish this, the ant workers were immobilized using gloved fingers (wearing surgical disposable gloves) and wooden tongs, taking care to prevent any type of damage to the ant worker. Similarly, for the control, the workers were treated with equal volume $(1.0 \mu \mathrm{L})$ of $70 \%$ ethyl alcohol. The sample unit involved a glass petri dish $(92 \mathrm{~mm}$ in diameter and $16 \mathrm{~mm}$ in height) supporting 10 workers from the same colony and a small cotton swab moistened every day with distilled water. Both the live and dead individuals (totally immobilized) were counted at 6,12, 24, 48 and 72 hours after each treatment. The percentage of workers that succumbed after the different $E$. pumila extracts were applied was corrected in relation to the control treatment (Abbott, 1925).

\subsection{Statistical Analyses}

Using the completely randomized experimental design with 10 replicates, the worker mortality was determined as a response to the dosage of the E. pumila fraction applied. The percentage of mortality of the ant workers in response to the concentrations of E. pumila fractions and the time after application (48 and 72 hours) were done using the Probit curve (Finney, 1971), which defined the lethal doses for the populations being tested $\left(\mathrm{LD}_{50}\right)$. The comparison of the toxicity of the different extracts for the two cutter-ant species was done employing Kruskal-Wallis non-parametric test, at $\mathrm{p}<0.001$, and the sample ranking was compared.

\section{Results}

Characterization reactions confirmed that the E. pumila leaves contained the following secondary metabolites: flavonoids, anthraquinones, coumarins, cardiac heterosides and tannins. However, the leaf extracts showed the absence of alkaloids and saponins.

The acute toxicity of all the E. pumila leaf extract fractions tested on the A. laevigata workers was confirmed 24 hours after topical application, i.e. the worker mortality increase at increasing concentrations of leaf fractions (Table 1). Despite showing a significant model, the dose-response curve for the EPFrE fraction presented an $\mathrm{LD}_{50}$ value of 213.38 , higher than the interval of the doses tested $\left(0.1\right.$ to $\left.200 \mathrm{~mL}^{-1}\right)$, indicating a lower acute toxicity for this ant in comparison with the other extracts. The EPFE fraction revealed the highest acute toxicity for the A. laevigata workers, presenting a lower $\mathrm{LD}_{50}$ and a higher coefficient of the angles of the mortality curve (0.0067).

The toxic effect of all the extracts was much clearer 72 hours after the topical application of the E. pumila leaf and fruit extracts in A. laevigata. Thus, all the extracts registered a significant drop of $\mathrm{LD}_{50}$ and revealed a delayed formicidal influence of all the extracts, regardless of the polarity of the solvent employed for the fractionation. For A. balzani, 24 hours after the topical application, only the EPFrE and EPFEA fractions showed $\mathrm{LD}_{50}$ value between the interval of the doses tested $\left(0.1\right.$ to $\left.200 \mathrm{~mL}^{-1}\right)$ (Table 1$)$. In contrast, lower $\mathrm{LD}_{50}$ was noted after 72 hours of the application, implying that the extract of the fraction EPFEA $\left(\operatorname{LD}_{50}=95.34\right)$, was more toxic to the $A$. balzani workers showing a value that was very close to that of the EPFrE fraction $\left(\operatorname{LD}_{50}=96.89\right)$.

The toxic effect of all the E. pumila extract fractions revealed greater toxicity only 48 hours after application on the leaf-cutting ant workers, and during the evaluation periods of 6,12 and 24 hours, in no application was the average percentage of dead individuals higher than $50 \%$ (Figures 2 and 3). In terms of the general worker 
mortality in each treatment, irrespective of the dose, 48 hours or 72 hours after applying different fractions of the E. pumila extracts no difference in toxicity was reported for the different extracts for the same ant (Kruskal-Wallis, $\mathrm{p}<0.001$ ) (Table 2). However, significant differences were recorded for the EPFE, EPFEH and EPFEM treatments, which demonstrated a higher mortality rate for A. laevigata after 48 hours. The higher toxicity of the E. pumila extracts for A. laevigata when compared to that for the A. balzani workers was evident 72 hours post application of all the extracts in the workers (Kruskal-Wallis, $\mathrm{p}<0.001$ ). For all the fractions tested, the toxicity in A. laevigata was higher than that in A. balzani (Table 2).

Table 1. Statistical analysis of the effect of six different E. pumila fractions on workers of Atta laevigata and Acromyrmex balzani

\begin{tabular}{|c|c|c|c|c|c|}
\hline \multirow{3}{*}{ Extract $^{*}$} & \multirow{3}{*}{ Regression $^{* *}$} & \multicolumn{4}{|c|}{ Exposure time after application } \\
\hline & & \multicolumn{2}{|c|}{ Atta laevigata } & \multicolumn{2}{|c|}{ Acromyrmex balzani } \\
\hline & & $48 \mathrm{~h}$ & $72 \mathrm{~h}$ & $48 \mathrm{~h}$ & $72 \mathrm{~h}$ \\
\hline \multirow[t]{4}{*}{ EPFrE } & $\mathrm{AC}(\mathrm{SE})$ & $0.0029(0.0007)$ & $0.0180(0.0019)$ & $0.0048(0.0609)$ & $0.0047(0.0007)$ \\
\hline & $\mathrm{LD}_{50}$ & 213.88 & 6.66 & 185.78 & 96.89 \\
\hline & $\left(\mathrm{CI}_{95}\right)$ & $(132.04-295.73)^{* * *}$ & $(0.93-12.38)$ & $(143.44-228.12)$ & $(72.97-120.82)$ \\
\hline & $\chi^{2}(\mathrm{p})$ & $18.4(<0.001)$ & $87.3(<0.001)$ & $48.8(0.001)$ & $47.6(0.001)$ \\
\hline \multirow[t]{4}{*}{ EPFE } & $\mathrm{AC}(\mathrm{SE})$ & $0.0067(0.0007)$ & $0.0418(0.0051)$ & $0.0014(0.0007)$ & $0.0020(0.0007)$ \\
\hline & $\mathrm{LD}_{50}$ & 91.67 & 5.38 & 495.43 & 200.00 \\
\hline & $\left(\mathrm{CI}_{95}\right)$ & $(69.65-113.69)$ & $(2.80-7.95)$ & $(67.68-927.19)^{* * *}$ & $(94.93-340.60)$ \\
\hline & $\chi^{2}(\mathrm{p})$ & $52.0(<0.001)$ & $66.7(<0.001)$ & $4.3(0.001)$ & $8.8(0.0001)$ \\
\hline \multirow[t]{4}{*}{ EPFED } & $\mathrm{AC}(\mathrm{SE})$ & $0.0056(0.0007)$ & $0.0154(0.0017)$ & $0.0039(0.0007)$ & $0.0050(0.0007)$ \\
\hline & $\mathrm{LD}_{50}$ & 123.75 & 9.37 & 232.00 & 117.46 \\
\hline & $\left(\mathrm{CI}_{95}\right)$ & $(99.26-148.24)$ & $(2.84-15.91)$ & $(165.81-300.19)^{* * *}$ & $(91.26-143.66)$ \\
\hline & $\chi^{2}(\mathrm{p})$ & $66.3(<0.001)$ & $80.3(<0.001)$ & $32.0(<0.001)$ & $53.3(<0.0001)$ \\
\hline \multirow[t]{4}{*}{ EPFEH } & $\mathrm{AC}(\mathrm{SE})$ & $0.0032(0.0007)$ & $0.0198(0.0021)$ & $0.0031(0.0007)$ & $0.0045(0.0007)$ \\
\hline & $\mathrm{LD}_{50}$ & 167.77 & 4.83 & 314.61 & 136.74 \\
\hline & $\left(\mathrm{CI}_{95}\right)$ & $(111.38-224.15)$ & $(0.00-10.14)$ & $(193.02-432.21)^{* * *}$ & $(103.44-170.05)$ \\
\hline & $\chi^{2}(p)$ & $23.1(0.001)$ & $68.4(<0.001)$ & $19.2(<0.001)$ & $43.5(<0.001)$ \\
\hline \multirow[t]{4}{*}{ EPFEM } & $\mathrm{AC}(\mathrm{SE})$ & $0.0029(0.0007)$ & $0.0182(0.0020)$ & $0.0030(0.0007)$ & $0.0047(0.0007)$ \\
\hline & $\mathrm{LD}_{50}$ & 131.38 & 14.46 & 335.97 & 137.30 \\
\hline & $\left(\mathrm{CI}_{95}\right)$ & $(81.92-180.85)$ & $(7.68-21.25)$ & $(198.86-473.08)^{* * *}$ & $(105.75-168.85)$ \\
\hline & $\chi^{2}(p)$ & $18.6(<0.001)$ & $86.1(<0.001)$ & $17.4(<0.001)$ & $48.7(<0.001)$ \\
\hline \multirow[t]{4}{*}{ EPFEA } & $\mathrm{AC}(\mathrm{SE})$ & $0.0042(0.0007)$ & $0.0153(0.0017)$ & $0.0039(0.0007)$ & $0.0047(0.0007)$ \\
\hline & $\mathrm{LD}_{50}$ & 135.95 & 21.26 & 195.56 & 95.34 \\
\hline & $\left(\mathrm{CI}_{95}\right)$ & (104.04-170.83) & $(13.56-28.96)$ & $(140.10-251.01)$ & $(71.54-119.15)$ \\
\hline & $\chi^{2}(\mathrm{p})$ & $39.3(<0.001)$ & $77.3(<0.001)$ & $32.5(<0.001)$ & $47.0(<0.001)$ \\
\hline
\end{tabular}

Note. *: EPFrE: Ethanolic fruit extracts of E. pumila; EPFE: Ethanolic leaf extracts of E. pumila; EPFED: Dichloromethane leaf extracts of E. pumila; EPFEH: hexane leaf extract of E. pumila; EPFEM: Methanolic leaf extract of E. pumila; EPFEA: Acetate-ethyl leaf extract of E. pumila.

**: AC (SE): Angular coefficient (standard error); $\mathrm{LD}_{50}\left(\mathrm{CI}_{95}\right)$ : Lethal dose for $50 \%$ of the population $(95 \%$ confidence interval); $\chi^{2}$ : Non-parametric chi-square test. $p$ : significance.

***: $\mathrm{LD}_{50}$ estimated beyond the range of 0.1 to $200 \mathrm{mg} \cdot \mathrm{mL}^{-1}$. 
Table 2. Comparison of the topical acute leaf and fruit toxicities of the Esenbeckia pumila extracts for workers of Atta laevigata and Acromyrmex balzani. Means followed by the same letter in lowercase in the column or uppercase in the row during the period of evaluation (48 or 72 hours post-application) do not differ between them (Kruskal-Wallis. $\mathrm{p}<0.001$ )

\begin{tabular}{|c|c|c|c|c|}
\hline \multirow{3}{*}{ Treatment $^{*}$} & \multicolumn{4}{|c|}{ Worker Mortality (\%) } \\
\hline & \multicolumn{2}{|c|}{$\begin{array}{c}48 \text { hours } \\
{\left[\mathrm{H}_{(13 . \mathrm{n}=912)}=242.89 ; \mathrm{p}<0.01\right]}\end{array}$} & \multicolumn{2}{|c|}{$\begin{array}{c}72 \text { hours } \\
{\left[\mathrm{H}_{(13 . \mathrm{n}=912)}=354.25 ; \mathrm{p}<0.01\right.}\end{array}$} \\
\hline & A. laevigata & A. balzani & A. laevigata & A. balzani \\
\hline Control & $00 \mathrm{bB}$ & $04 \mathrm{bA}$ & $09 \mathrm{bA}$ & $13 \mathrm{bA}$ \\
\hline EPFrE & $36 \mathrm{aA}$ & $29 \mathrm{aA}$ & $68 \mathrm{aA}$ & $45 \mathrm{aB}$ \\
\hline EPFE & $47 \mathrm{aA}$ & $29 \mathrm{aB}$ & $71 \mathrm{aA}$ & $40 \mathrm{aB}$ \\
\hline EPFED & $39 \mathrm{aA}$ & $27 \mathrm{aA}$ & $68 \mathrm{aA}$ & $40 \mathrm{aB}$ \\
\hline EPFEH & $40 \mathrm{aA}$ & $23 \mathrm{aB}$ & $70 \mathrm{aA}$ & $38 \mathrm{aB}$ \\
\hline EPFEM & $46 \mathrm{aA}$ & $22 \mathrm{aB}$ & $75 \mathrm{aA}$ & $37 \mathrm{aB}$ \\
\hline EPFEA & $41 \mathrm{aA}$ & $32 \mathrm{aA}$ & $71 \mathrm{aA}$ & $45 \mathrm{aB}$ \\
\hline
\end{tabular}

Note. *: EPFrE: Ethanolic fruit extract of E. pumila; EPFE: Ethanolic leaf extract of E. pumila; EPFED: Dichloromethane leaf extract of E. pumila; EPFEH: hexane leaf extract of E. pumila; EPFEM: Methanolic leaf extract of E. pumila; EPFEA: Ethyl acetate leaf extract of E. pumila. 
EPFrE

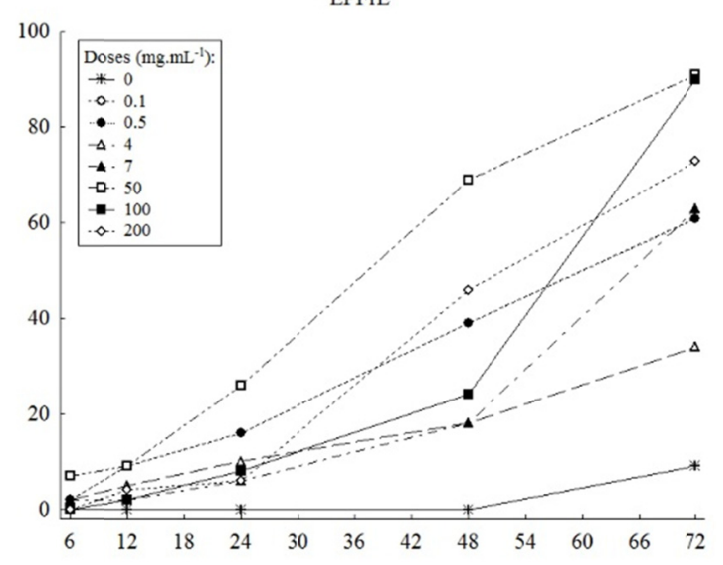

EPFED

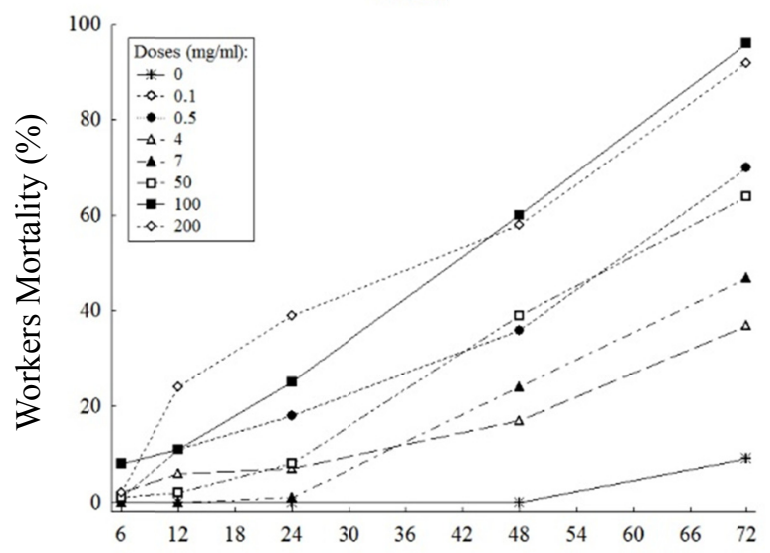

EPFEM

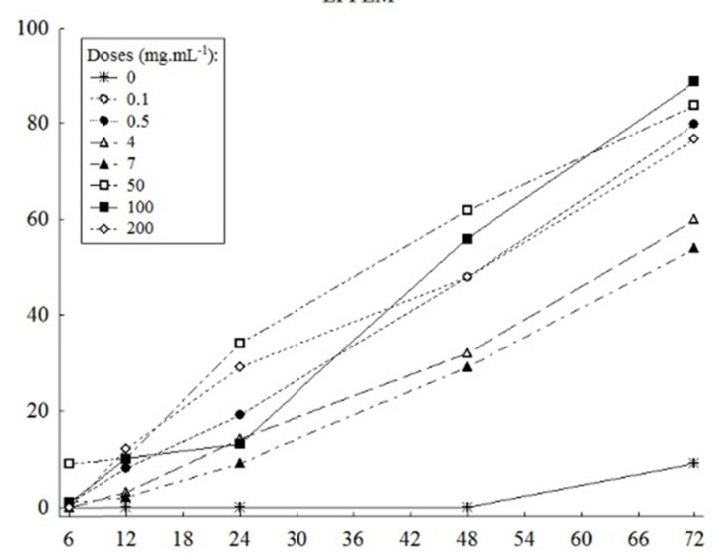

EPFE

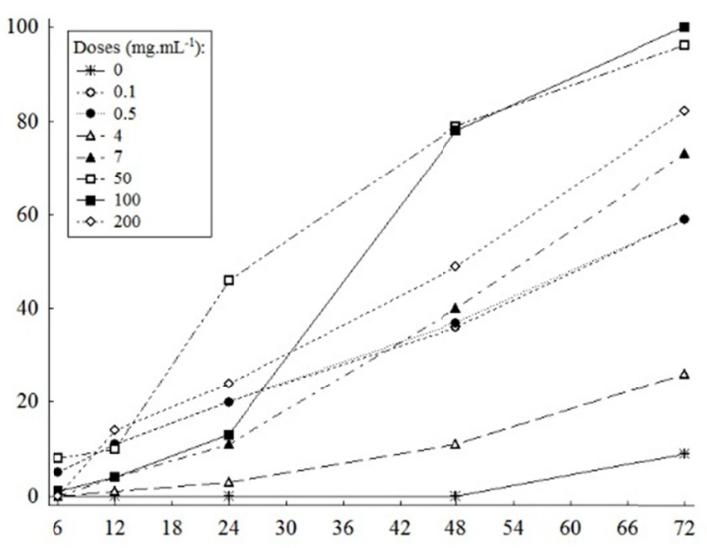

EPFEH

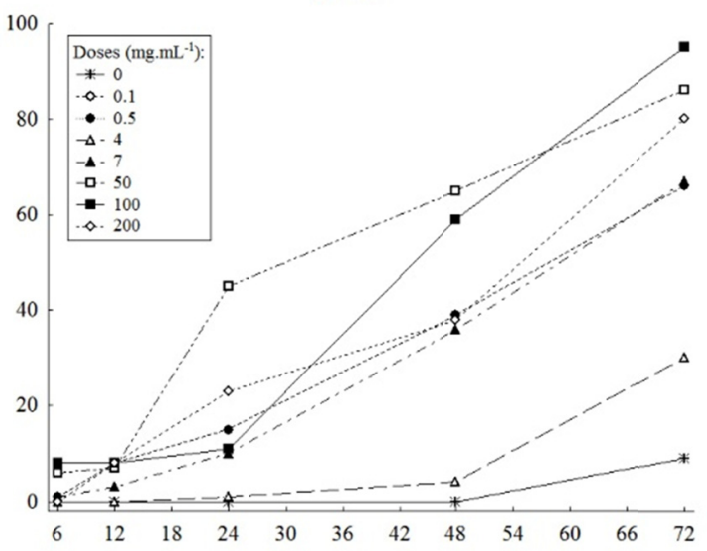

EPFEA

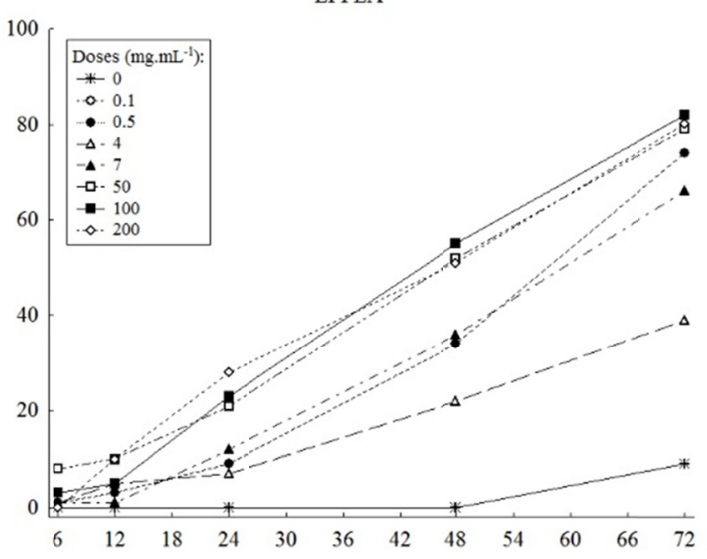

Time (hours)

Figure 1. Mortality of the Atta laevigata workers after topical application of different leaf and fruit extract concentrations of Esenbeckia pumila. (EPFrE: Ethanolic fruit extract of E. pumila; EPFE: Ethanolic leaf extract of E. pumila; EPFED: Dichloromethane leaf extract of E. pumila; EPFEH: Hexanic leaf extract of E. pumila;

EPFEM: Methanolic leaf extract of E. pumila; EPFEA: Ethyl acetate leaf extract of E. pumila) 
EPFrE

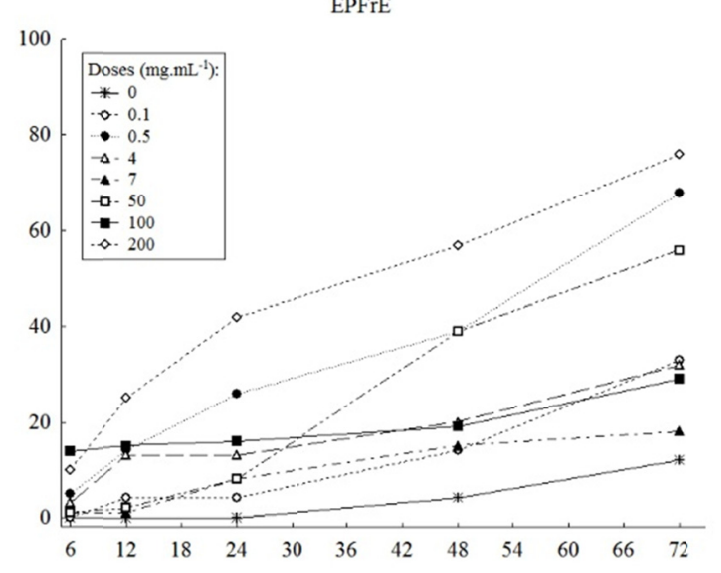

EPFED

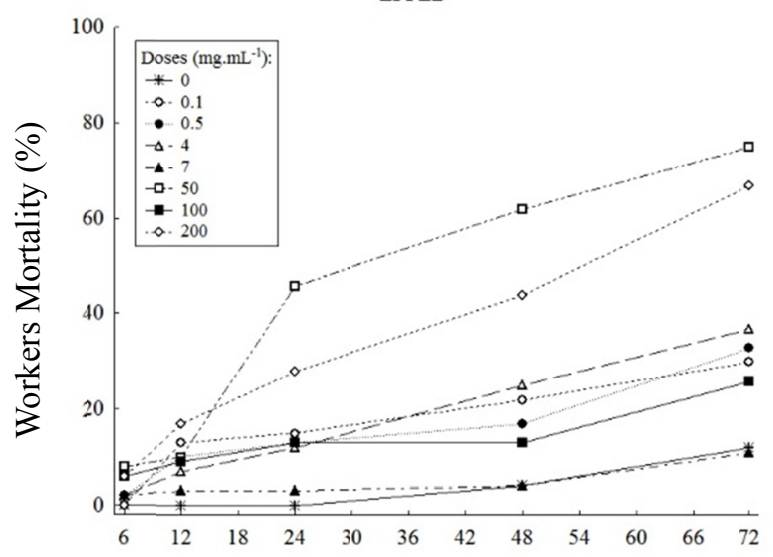

EPFEM

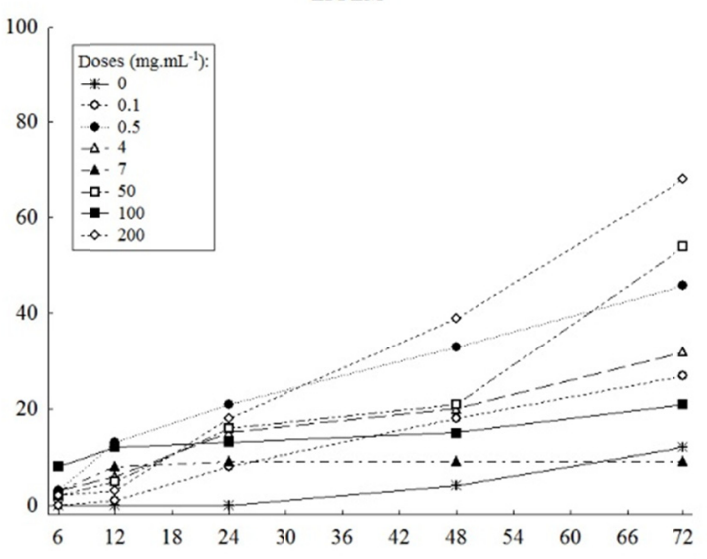

EPFE

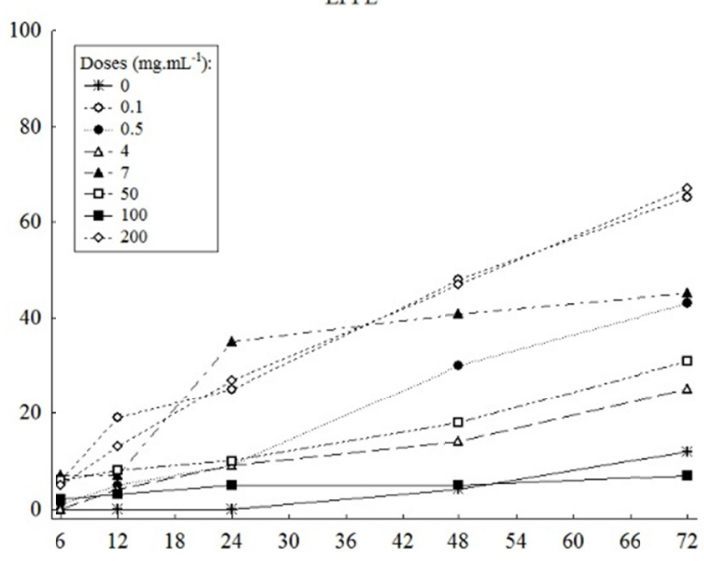

EPFEH

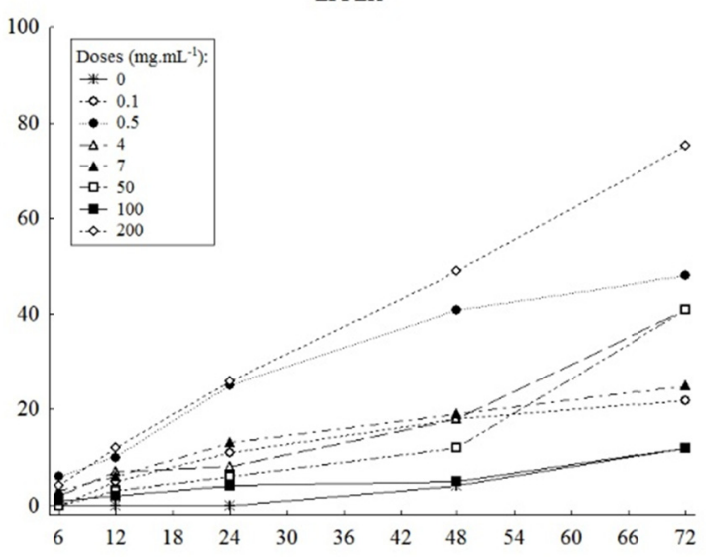

EPFEA

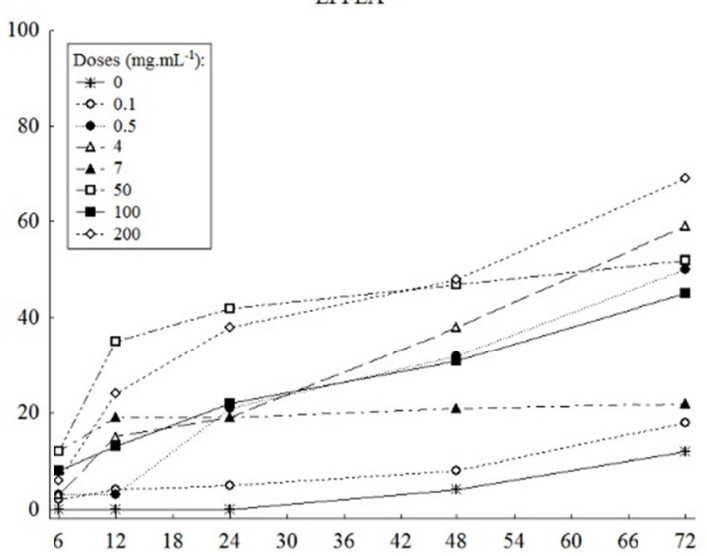

Time (hours)

Figure 2. Mortality of the Acromyrmex balzani workers after topical application of different leaf and fruit extract concentrations of Esenbeckia pumila (EPFrE: Ethanolic fruit extract of E. pumila; EPFE: Ethanolic leaf extract of E. pumila; EPFED: Dichloromethane leaf extract of E. pumila; EPFEH: Hexanic leaf extract of E. pumila;

EPFEM: Methanolic leaf extract of E. pumila; EPFEA: Ethyl acetate leaf extract of E. pumila) 


\section{Discussion}

This study shows that the chemical compounds identified in the extracts, individually or in synergy, were responsible for the mortality of the A. laevigata and A. balzani workers. A few of the secondary compounds identified during phytochemical prospecting have been reported earlier as potential insecticidal or antifeedant activity for certain insect groups. A few specific flavonoids are known to act as antifeedant agents, for example, ermanin and rutin (Echeverri et al., 1991; Silva et al., 2016) and insect growth inhibitors (Simmonds, 2003), most likely as they interfere with the neural mechanisms whose toxic actions are influenced by the chemical structure of each specific compound. The coumarin is known to inhibit the electron transport chair (Neal \& Wu, 1994) and also compromises the detoxification capacity of insects, which reduces, for example, their tolerance to xenobiotics (Moreira et al., 2007). The cardioactive glycosides (terpenoids) are well-recognized drugs that influence vertebrate cardiac muscles (Taiz \& Zeiger, 2004), but they have not yet specifically been investigated in insects. The E. pumila leaves showed the presence of tannins which normally act as a protective barrier for the plant against herbivorous insects (Correa \& Salgado, 2011) and anthraquinone. The latter is better known for its effectiveness as a laxative drug, besides being a plant defense against xylophagous, as verified in Tectona grandis (Leonardo, Rocha, \& Mendoza, 2015).

In A. balzani and A. laevigata, the toxic effects of E. pumila extracts were the responsible of the delayed formicidal activity, clearly highlighted 72 hours post-application. The concept behind using these plant extracts to manufacture granulated baits is that the poison will slowly cause the death of the workers according to Gouveia et al. (2010). However, Della Lucia and Araújo (2000) reported that the workers must live long enough after coming into contact with the active principle of the venom in order to have adequate time to distribute the bait to their fellow companions within the nests, including the queen. The $\mathrm{LD}_{50}$ variable shows a delayed effect, which was the reason for dubbing the EPFrE extract as one of the most toxic to the Atta and Acromyrmex workers (Table 1). However, it is understood that the seeds possess greater potential to store the toxic active compounds and therefore have been investigated more extensively as pesticides (Rodrigues, 2000). In this study the fractionation of ethanolic extract of fruits was not possible to be performed, due to the reduced amount of fruits collected. In general, did not observe a significant prominence in the toxicity of leaf or fruit extracts (Table 2). The proportions of secondary metabolites in parts of the plants occur at different levels (seasonal and daily, intra and interspecific). Several factors can cause variations in the content of the secondary plant metabolites. Among them, Gobbo-Neto and Lopes (2007) quoted the harvest season, plant age, altitude and seasonality, physiological factors (e.g. affected by water stress), luminosity and nutritional status of the plant.

The lesser degree of toxicity of the insecticides and plant extracts associated with higher robustness levels of the insect body was stated by Maciel et al. (2010) with Diptera. A similar observation was made by Araújo et al. (2008) on comparing the plant extract toxicity in A. laevigata and A. subterraneus subterraneus. These authors also confirmed greater toxicity in the Acromyrmex workers, who showed smaller worker sizes. However, this fact was not confirmed in this study, as generally the extracts showed greater toxicity in A. laevigata. São João and Raga (2016) ascertained that the toxicity of a specific secondary compound will depend on the species under investigation, often revealing even antagonistic effects for different species.

\section{Conclusion}

Fractionation of the plant extracts is the primary step in identifying more formicidal compounds as effective alternatives to control the leaf-cutting ants. The present study revealed that irrespective of the degree of polarity of the solvent, the degree of toxicity to the leaf-cutting ants A. laevigata or A. balzani was not significantly different. Applying solvents having different degrees of polarity and the lack of a predominant fraction of the most toxic extract indicate the absence of a single compound as the key factor to mortality or even the low formicidal efficiency of all the possible secondary compounds present in E. pumila.

\section{Acknowledgements}

To "Universidade Estadual de Goiás" for facilitating this work through research grants (PPGPV and BIP programs).

\section{References}

Abbott, W. S. (1925). A method of computing the effectiveness of an insecticide. Journal of Economic Entomology, 18, 265-266. https://doi.org/10.1093/jee/18.2.265a

Aguiar-Menezes, E. L. (2005). Inseticidas Botânicos: Seus Princípios Ativos, Modo de Ação e Uso Agrícola (Documentos). Seropédica: Embrapa Agrobiologia, Seropédica. 
Almeida, R. N. A., Peñaflor, M. F. G. V., Simote, S. Y., Bueno, O. C., Hebling, M. J. A., Pagnocca, F. C., ... Silva, M. F. G. F. (2007). Toxicity of substances isolated from Helietta puberula RE Fr. (Rutaceae) to the leaf-cutting ant Atta sexdens L. (Hymenoptera: Formicidae) and the symbiotic fungus Leucoagaricus gongylophorus (Singer) Moeler. BioAssay, 2, 1-8.

Araújo, M. S., Della Lucia, T. M. C., Moreira, M. D., \& Picanço, M. C. (2008). Toxicidade de extratos hexânicos de plantas às operárias de Atta laevigata e Acromyrmex subterraneus subterraneus (Formicidae: Attini). Revista Brasileira de Agrociência, 14, 106-114.

Barroso, G. M., Guimarães, E. F., Ichaso, C. L. F., Costa, C. G., Peixoto, A. L., \& Lima, H. C. (1986). Sistemática de Angiospermas do Brasil. Viçosa: Universidade Federal de Viçosa.

Baskar, K., \& Ignacimuthu, S. (2012). Antifeedant, larvicidal and growth inhibitory effects of ononitol monohydrate isolated from Cassia tora L. against Helicoverpa armigera (Hub.) and Spodoptera litura (Fab.) (Lepidoptera: Noctuidae), Chemosphere, 88, 384-388. https://doi.org/10.1016/j.chemosphere.2012.02.051

Baskar, K., Maheswaran, R., Kingsley, S., \& Ignacimuthu, S. (2011). Bioefficacy of plant extracts against Asian armyworm Spodoptera litura Fab. (Lepidoptera: Noctuidae) larvae. International Journal of Agricultural Technology, 7(1), 123-131.

Corrêa, J. C. R., \& Salgado, H. R. N. (2011). Atividade inseticida das plantas e aplicações: Revisão. Revista Brasileira de Plantas Medicinais, 13(4), 500-506. https://doi.org/10.1590/S1516-05722011000400016

Costa, A. F. (2001). Farmacognosia (3rd ed.). Lisboa: Fundação Calouste Gulbenkian.

Della Lucia, T. M. C., \& Araújo, M. S. (2000). Formigas cortadeiras: Atualidades no combate. In L. Zambolim (Ed.), Manejo Integrado: Doenças, Pragas e Plantas Daninhas (Vol. 1, pp. 26-31). Viçosa, Brasil: Suprema Gráfica.

Echeverri, F., Cardona, G., Torres, F., Pelaez, C., Quiñones, W., \& Renteria, E. (1991). Ermanin: an insect deterrent flavonoid from Passiflora foetida resin. Phytochemistry, 30, 153-155. https://doi.org/10.1016/ 0031-9422(91)84116-A

Finney, D. J. (1971). Probit analysis (3rd ed.). New York: Cambridge University Press.

Gobbo-Neto, L., \& Lopes, N. P. (2007). Plantas medicinais: Fatores de influência no conteúdo de metabólitos secundários. Quimica Nova, 30(2), 374-381. https://doi.org/10.1590/S0100-40422007000200026

Gomes, M. C. A. R., Paula, V. F., Moreira, A. A., Castellani, M. A., \& Macedo, G. E. L. (2016). Toxicity of plant extracts from Bahia, Brazil, to Atta sexdens sexdens (Hymenoptera: Formicidae) workers. Sociobiology, 63(2), 770-776. https://doi.org/10.13102/sociobiology.v63i2.936

Gouveia, S. M., Carvalho, G. A., Picanço, M. C., Morais, E. G. F., Benevenute, J. S., \& Moreira, M. D. (2010). Lethal and behavioral effects of amazonian plant extracts on leaf-cutting ant (Hymenoptera: Formicidae) workers. Sociobiology, 56: 1-10.

Grainge, M., \& Ahmed, S. (1998). Handbook of plants with pest-control proprieties. Chichester, UK: John Wiley \& Sons Ltd.

Groppo, M., Pirani, J. R., Salatino, M. L. F., Blanco, S. R., \& Kallunki, J. A. (2008). Phylogeny of Rutaceae based on two noncoding regions from cpDNA. American Journal of Botany, 95(8), 985-1005. https://doi.org/10.3732/ajb.2007313

Hebling, M. J. A., Maroti, P. S., Bueno, O. C., Silva, O. A., \& Pagnocca, F. C. (1996). Toxic effects of leaves of Ricinus communis (Euphorbiaceae) to laboratory nests of Atta sexdens rubropilosa (Hymenoptera: Formicidae). Bulletin of Entomological Research, 86, 253-256. https://doi.org/10.1017/S00074853000 52536

Leonardo, F. V. S., Rocha, H. F., \& Mendoza, Z. M. S. H. (2015). Compostos químicos em teca. Pesquisa Florestal Brasileira, 35, 315-322. https://doi.org/10.4336/2015.pfb.35.83.816

Mabberley, D. J. (2008). Mabberley's plant-book: A portable dictionary of plants, their classification and uses. Cambridge, UK: Cambridge University Press.

Maciel, M. V., Morais, S. M., Bevilaqua, C. M. L., \& Amóra, S. S. A. (2010). Extratos vegetais usados no controle de dípteros vetores de zoonoses. Revista Brasileira de Plantas Medicinais, 12(1), 105-112. https://doi.org/10.1590/S1516-05722010000100015 
Marsaro Júnior, A. L., Souza, R. C., Della Lucia, T. M. C., Fernandes, J. B. B., Silva, M. F. G. F., \& Vieira, P. C. (2004). Behavioral changes in workers of the leaf-cutting ants Atta sexdens rubropilosa induced by chemical compounds of Eucalyptus maculata leaves. Journal of Chemical Ecology, 30, 1771-1780. https://doi.org/10.1023/B:JOEC.0000042400.14451.08

Matos, F. J. A. (2009). Introdução à fitoquímica experimental (3rd ed.). Fortaleza, Brazil: UFC.

Matos, J. M. D., \& Matos, M. E. (1989). Farmacognosia. Fortaleza, Brazil: UFC.

Mazzonetto, F., \& Vendramim, J. D. (2003). Efeito de pós de origem vegetal sobre Acanthoscelides obtectus (Say) (Coleoptera: Bruchidae) em feijão armazenado. Neotropical Entomology, 32(1),145-149. https://doi.org/10.1590/S1519-566X2003000100022

Medeiros, J. D. (2011). Guia de Campo: Vegetação do Cerrado-500 Espécies. Instituto Brasileiro do Meio Ambiente e dos Recursos Naturais Renováveis (MMA/SBF), Brasília, Brazil.

Melo, M. F. F., \& Zickel, C. S. (2004). Os gêneros Zanthoxylum L. e Esenbeckia Kunth (Rutaceae) no Estado de Pernambuco, Brasil. Acta Botanica Brasilica, 18(1), 73-90. https://doi.org/10.1590/S0102-3306200400 0100007

Moreira, M. D., Picanço, M. C., Barbosa, L. C. A., Guedes, R. N. C., Campos, M. R., Silva, G. A., \& Martins, J. C. (2007). Plant compounds insecticide activity against Coleoptera pests of stored products. Pesquisa Agropecuária Brasileira, 42(7), 909-915. https://doi.org/10.1590/S0100-204X2007000700001

Morini, M. S. C., Bueno, O. C., Bueno, F. C., Leite, A. C., Hebling, M. J. A., Pagnocca, F. C., ... Silva, M. F. G. F. (2005). Toxicity of sesame seed to leaf-cutting ant Atta sexdens rubropilosa (Hymenoptera: Formicidae). Sociobiology, 45(1), 195-204.

Neal, J. J., \& Wu, D. (1994). Inhibition of insect cytochromes P450 by furanocoumarins. Pesticide Biochemistry and Physiology, 50, 43-50. https://doi.org/10.1006/pest.1994.1056

Paula, J. R., Vieira, I. J. C., Silva, M. F. G. F., Rodrigo-Filho, E., Fernandes, J. B., Vieira, P. C., ... Vilela, E. F. (1997). Sesquisterpenes, triterpenoids, limonoids and flavonoids of Cedrela odorata graft and speculations on the induced resistance against Hypsipyla grandela. Phytochemistry, 44, 1449- 1454. https://doi.org/ 10.1016/S0031-9422(96)00747-9

Rodríguez, H. C. (2000). Plantas contra plagas: potencial práctico de ajo, anona, nim, chile y tabaco (p. 133). Texcoco, Mexico: Red de Acción sobre Plaguicidas y Alternativas en México (RAPAM).

São João, R. E., \& Raga, A. (2016). Mecanismo de defesa das plantas contra o ataque de insetos sugadores (Documento Técnico 23). São Paulo, Brazil: Instituto Biológico-APTA.

Silva, T. R. F. B., Almeida, A. C. S., Moura, T. L., Silva, A. R., Freitas, S. S., \& Jesus, F. G. (2016). Effect of the flavonoid rutin on the biology of Spodoptera frugiperda (Lepidoptera: Noctuidae). Acta Scientiarum, 38(2), 165-170. https://doi.org/10.4025/actasciagron.v38i2.27956

Simmonds, M. S. J. (2003). Flavonoid-insect interactions: recent advances in our knowledge. Phytochemistry, 64, 21-30. https://doi.org/10.1016/S0031-9422(03)00293-0

Simões, C. M. O. (2010). Farmacognosia: da Planta ao Medicamento (6th ed.). Florianópolis, Brazil: UFSC.

Simpson, D. S., \& Jacobs, H. (2005). Alcaloids and coumarins from Esenbeckia pentaphylla (Rutaceae). Biochemical Systematics and Ecology, 33, 941-844. https://doi.org/10.1016/j.bse.2004.12.022

Solecki, R. (2004). Toxicology of miscellaneous insecticides. In T. C. Marrs \& B. Ballantyne (Eds.), Pesticide Toxicology and International Regulation (pp. 159-189). Chichester, UK: John Wiley \& Sons, Ltd.

Taiz, L., \& Zeiger, E. (2004). Fisiologia vegetal (3th ed.). Porto Alegre, Brazil: Artmed.

Talukder, F. A., \& Howse, P. E. (1994). Laboratory evaluation of toxic and repellent properties of the pithraj tree, Aphanamixis polystachya Wall \& Parker, against Sitophilus oryzae (L.). International Journal of Pest Management, 40, 274-279. https://doi.org/10.1080/09670879409371897

Upadhyay, R. K. (2012). Insecticidal and oviposition inhibition efficacy of Capparis decidua to Sitophilus oryzae Linn. (Coleoptera: Curculionidae). International Journal of Chemical and Biochemical Sciences, 2, 14-23.

Vendan, S. E., Baskar, K., Paulraj, M. G., \& Ignacimuthu, S. (2016). Antifeedant and larvicidal effects of Hydnocarpus alpine Wt. (Flacourtiaceae) extracts against the larvae of Helicoverpa armigera Hub. 
(Lepidoptera: Noctuidae). In S. Ignacimuthu \& B. V. David (Eds.), Ecofriendly Insect Pest Management (Vol. 1, pp. 210-216). New Delhi: India Elite Publishing House.

\section{Copyrights}

Copyright for this article is retained by the author(s), with first publication rights granted to the journal.

This is an open-access article distributed under the terms and conditions of the Creative Commons Attribution license (http://creativecommons.org/licenses/by/4.0/). 